\title{
HUBUNGAN KARAKTERISTIK PASIEN DENGAN TOKSISITAS HEPATOLOGI AKIBAT PENGGUNAAN 6-MERKAPTOPURIN DALAM FASE PEMELIHARAAN PADA PASIEN PEDIATRI KANKER LEUKIMIA LIMFOBLASTIK AKUT DI RS KANKER DHARMAIS JAKARTA
}

\author{
Nazhipah Isnani ${ }^{1}$, Dyah Aryani Perwitasari ${ }^{2}$,Rizka Andalusia ${ }^{3}$, Haridini Intan \\ $\mathrm{Mahdi}^{3}$ \\ ${ }^{1}$ Program Studi D-III Farmasi Politeknik Unggulan Kalimantan \\ ${ }^{2}$ Fakultas Farmasi Universitas Ahmad Dahlan Yogyakarta \\ ${ }^{3}$ Rumah Sakit Kanker Dharmais Jakarta \\ *: isnaninazhipah@gmail.com
}

\begin{abstract}
ABSTRAK
Merkaptopurin adalah obat kemoterapi yang digunakan dalam fase konsolidasi dan pemeliharaan pada pasien anak-anak dengan leukemia limfoblastik akut (ALL). Merkaptopurin seharusnya memiliki hubungan dengan terjadinya toksisitas dalam hepatologi. Penelitian ini bertujuan untuk mengetahui angka kejadian pasien, derajat keparahan dan manajemen toksisitas serta faktor risiko yang mempengaruhi terjadinya toksisitas hepatologi penggunaan 6 - MP pada fase pemeliharaan pada pasien anak dengan leukemia limfoblas akut di RS Kanker Dharmais Jakarta. Penelitian ini dilakukan dengan desain observasional cross sectional dengan pengambilan data secara retrospektif dan prospektif selama periode bulan Maret sampai dengan April 2014. Subjek penelitian adalah pasien yang telah menjalani perawatan fase perawatan di RS Kanker Dharmais Jakarta dari tahun 2013 sampai dengan Maret- April 2014. Subjek yang memenuhi kriteria inklusi sebanyak 23 pasien ALL menerima 6 - MP pada fase maintenance. Pengumpulan data dilakukan dengan melihat rekam medis untuk mendapatkan identitas pasien dan data hepatologi. Hasil penelitian menunjukkan bahwa ada hubungan antara karakter pasien dengan toksisitas hepatologi, umur dan berat badan SGOT dengan SGPT keduanya memiliki nilai signifikan yaitu 0,036 (P $<0,05)$.
\end{abstract}

Kata kunci: 6-merkaptopurin, toksisitas, hepatologi, leukemia limfoblastik akut

\section{ABSTRACT}

Mercaptopurine is a chemotherapy drug that used in the consolidation and maintenance phase in pediatric patients with acute lymphoblastic leukemia (ALL). Mercaptopurine is supposed to have relationship with the occurrence of toxicity in hepatology. This study was aimed to determine the patient incidence, severity and management of toxicity and risk factors that affect the occurrence of hepatologic toxicity using of 6 - MP in the maintenance phase in pediatric patients with acute lymphoblastic leukemia in Dharmais Cancer Hospital Jakarta. 
Jurnal Insan Farmasi Indonesia, 3(2) Desember 2020 (361-368)

Nazhipah Isnani

p-ISSN 2621-3184 ; e-ISSN 2621-4032

doi: $10.36387 /$ jifi.v3i2.585

This research was carried out by cross-sectional observational design with data was taken retrospectively and prospectively during the period from March to April 2014. The study subjects were patient who have been getting treatment of maintenace phase in Dharmais Cancer Hospital Jakarta from 2013 until March-April 2014. The Subjects who met the inclusion criteria were 23 patients of ALL received 6 - MP in the maintenance phase. Data was collected by looking at the medical records for getting of the patient's identity and data hepatology. The result showed that there was a correlation between patient characterision on hepatology toxicity, on SGOT age and weight with SGPT both of them has significant value, it was $0,036(P<0,05)$

Keywords : 6-mercaptopurine, toxicity, hepatology, acute lymphoblastic leukemia

\section{PENDAHULUAN}

Leukimia merupakan penyakit keganasan sel darah yang berasal dari sumsum tulang. Biasanya ditandai oleh proliferasi sel-sel darah putih dengan manifestasi adanya sel-sel abnormal dalam darah tepi secara berlebihan ${ }^{1}$. Leukimia limfositik akut atau yang juga biasa disebut leukimia limfoblastik akut (LLA) adalah keganasan yang paling umum terjadi pada anak dan didiganosis pada anak $<15$ tahun serta merupakan penyumbang $78 \%$ dari leukimia pada anak ${ }^{2}$. Data lain menunjukkan bahwa LLA terdiri dari 75\%-80\% dari semua leukemia yang didiagnosis pada anak. Secara epidemiologi, kejadian leukemia sebesar 30-40\% dari seluruh keganasan pada anak. Puncak kejadianterjadi pada usia 2-5 tahun dan angka kejadian anak dibawah usia 15 tahun rata-rata 44,5/100.000 per tahun. Di RS Kanker "Dharmais" (RSKD), setiap tahun ratarataditemukan 10 kasus baru leukemia akut pada anak danselalu menduduki urutan pertama dari 10 jenis kanker terbanyak pada anak. Sementara itu, sejak 2006-2010,angka kematian leukemia pada fase pengobatan apapundi Rumah Sakit Cipto Mangunkusumo (RSCM) dan RSKD sebesar $20-30 \%{ }^{3}$.

Pengobatan dengan kemoterapi merupakan terapi kuratif utama pada leukimia Merkaptopurin (6-MP) adalah prodrug yang telah digunakan selama 35 sampai 40 tahun terakhir dalam pengobatan kanker LLA pada anak-anak ${ }^{3}$.Menurut Indonesian Protocol ALL (2006) yang digunakan di RS Kanker Dharmais, 6-MP digunakan 
Jurnal Insan Farmasi Indonesia, 3(2) Desember 2020 (361-368)

Nazhipah Isnani

p-ISSN 2621-3184 ; e-ISSN 2621-4032

doi: $10.36387 /$ jifi.v3i2.585

pada fase pemeliharaan dan konsolidasi

pasien resiko biasa dan pasien resiko

tinggi. Merkaptopurin berhubungan dengan hepatotoksisitas dan mielosupresi ${ }^{4}$.

Hepatotoksisitas
peningkatan enzim adalah
aminotransferase
dist) atau biasa
disebut dengan serum glutamic
oxaloacetic transaminase (SGOT) dan aspartate aminotransferase (AST) atau disebut dengan serum glutamic piruvic transaminase (SGPT) tiga kali dari batas normal atas $^{5}$. Hepatoksisitas yang terjadi pada pasien anak yang menggunakan 6-MP pada fase pemeliharaan dilaporkan sebesar $72 \%$. Terjadinya hepatoksisitas berhubungan dengan 6-methylated metabolite (6MMPN) yang merupakan metabolit dari 6-MP melalui jalur katabolisme ${ }^{6}$. Kemoterapi menginduksi hepatotoksisitas adalah penyebab umum dari tes fungsi hati yang abnormal pada pasien ${ }^{5}$.Berdasarkan penelitian yang terdahulu perlu dilakukan evaluasi toksisitas terhadap pasien yang mendapatkan terapi 6-MP.
Tujuan dari penelitian ini adalah untuk mengetahui karakteristik pasien pediatri yang menggunakan 6-MP pada fase pemeliharaan dan untuk mengetahui hubungan antara karateristik pasien dengan toksisitas hepatologi penggunaan 6-MP dalam fase pemeliharaan pada pasien pediatri kanker leukimia limfoblastik akut di RS Kanker Dharmais Jakarta.

\section{METODE PENELITIAN}

Penelitian ini dilakukan dengan desain observasional cross sectional dengan mengambil data pasien selama periode Maret-April 2014. Pengambilan data secara retrospektif yaitu pasien yang dijadikan subyek penelitian adalah pasien kanker LLA yang sudah dilakukan kemoterapi dengan 6-MP di RS Kanker Dharmais, Jakarta sejak tahun 2013. Pengambilan data secara prospektif yaitu pasien yang berobat sejak tahun 2013 tersebut diikuti perjalanannya dalam penggunaan 6-MP sampai dengan bulan April 2014. Subyek penelitian adalah pasien kanker LLA anak yang berobat di RS Kanker Dharmais Jakarta 
Jurnal Insan Farmasi Indonesia, 3(2) Desember 2020 (361-368)

Nazhipah Isnani

p-ISSN 2621-3184 ; e-ISSN 2621-4032

doi: $10.36387 /$ jifi.v3i2.585

dari tahun 2013 sampai dengan periode Maret-April 2014 yang sedang dalam fase pemeliharaan. Kriteria inklusi dalam penelitian ini adalah pasien anak penderita LLA yang berusia 0 hingga 18 tahun, telah menjalani kemoterapi dengan 6-MP pada fase pemeliharaan pada tahun 2013, sedang menjalani kemoterapi dengan 6-MP dan telah selesai kemoterapi fase pemeliharaan dan kontrol di poli rawat jalan RS Kanker Dharmais Jakarta periode Maret-April 2014 dan memiliki data hepatologi. Karakteristik pasien dengan toksisitas hepatologi dengan menggunakan regresi linear. Alat yang digunakan dalam penelitian ini adalah formulir penelitian yang digunakan untuk mencatat data yang telah didapatkan dari rekam medis.

\section{HASIL DAN PEMBAHASAN}

Pada penelitian ini toksisitas hepatologi dilihat berdasarkan pemeriksaan rutin pada nilai SGOT dan SGPT dikategorikan derajat keparahannya menurut Common Toxicity Criteria (ECOG, 2007). Pada pasien dengan diagnosa LLA risiko biasa fase pemeliharaan kemoterapi dilakukan selama 98 minggu dan diagnosa LLA risiko tinggi fase pemeliharaan kemoterapi dilakukan selama 92 minggu

Tabel 1. Karakteristik subyek penelitian

\begin{tabular}{lcc}
\hline $\begin{array}{c}\text { Karekteristik Subyek } \\
\text { Penelitian }\end{array}$ & $\begin{array}{c}\sum_{\text {(n 23) }} \\
\text { Jenis Kelamin }\end{array}$ & $\mathbf{\%}$ \\
Laki- Laki & 16 & 69,56 \\
Perempuan & 7 & 30,44 \\
Usia & & \\
$<10$ tahun & 16 & 69,56 \\
$\geq 10$ tahun & 7 & 30,44 \\
Status Gizi & & \\
Sangat kurus & 0 & 0 \\
Kurus & 0 & 0 \\
Normal & 15 & 65,22 \\
Gemuk & 0 & 0 \\
Obesitas & 8 & 34,78 \\
Klasifikasi LLA & & \\
LLA Risiko Biasa & 10 & 43,48 \\
LLA Risiko Tinggi & 13 & 56,52 \\
Immunophenotyping & & \\
Sel B & 16 & 88,89 \\
Sel T & 2 & 11,11 \\
\hline
\end{tabular}

Pada tabel I diuraikan data karakteristik subyek penelitian. Pada jenis kelamin subyek yang paling banyak menderita LLA adalah pada jenis kelamin laki-laki dibandingkan perempuan. Hal ini sesuai dengan kepustakaan bahwa laki-laki memang 
Jurnal Insan Farmasi Indonesia, 3(2) Desember 2020 (361-368)

Nazhipah Isnani

p-ISSN 2621-3184 ; e-ISSN 2621-4032

doi: $10.36387 /$ jifi.v3i2.585

lebih banyak menderita LLA dibandingkan perempuan dengan rasio laki-laki dan perempuan adalah $1: 2^{3}$. Sedangkan untuk usia, subyek penelitian dikelompokkan menjadi 2 kelompok usia yaitu subyek penelitian yang berusia $<10$ tahun sebanyak 16 subyek penelitian $(69,56 \%)$ dan subyek penelitian yang berusia $\geq 10$ tahun sebanyak 7 subyek $(30,44 \%)$. Hal tersebut sesuai dengan penelitian terdahulu bahwa kanker LLA memang banyak terjadi pada usia kurang dari 10 tahun? ${ }^{7}$.

Terkait status gizi, pada penelitian ini diperoleh hasil bahwa status gizi sangat kurus dan kurus tidak ada $(0 \%)$, normal 15 orang anak $(65,22 \%)$, gemuk tidak ada ( $0 \%)$, dan obesitas 8 orang anak $(34,78 \%)$. Pada penelitian ini, status gizi anak penderita. LLA kebanyakan memliki status gizi normal. Beberapa penelitian berpendapat bahwa pada anak LLA jarang mengalami status gizi buruk, hal tersebut dikarenakan bahwa penderita LLA diberikan obat kortikosteroid saat dilakukan kemoterapi sehingga bisa menyebabkan obesitas ${ }^{3}$.

Immunophenotyping digunakan sebagai suatu penanda dalam klasifikasi leukimia limfoblastik akut ${ }^{8}$. Immunophenotyping dikelompokkan menjadi 2 sesuai dengan klasifikasi WHO yaitu sel B dan sel T. Sedangkan, pada klasifikasi LLA pada penelitian ini paling banyak terjadi pada pasien dengan risiko tinggi dibandingkan dengan risiko biasa. Berdasarkan teori, pasien LLA berdasarkan usia 1 sampai 9,99 tahun dan jumlah leukosit $\leq$ 50.000/ul (risiko biasa); serta usia $>10$ tahun dan/atau jumlah leukosit $\geq 50.000 /$ ul (risiko tinggi) ${ }^{9}$. Hal tersebut sesuai dengan penelitian ini bahwa subyek dengan resiko tinggi 13 (56,52\%) lebih banyak dibandingkan dengan risiko biasa sebanyak 10 $(43,48 \%)$.

Kemudian

untuk mmunophenotyping, pada d penelitian ini hanya terdapat 19 subyek penelitian yang memiliki data immunophenotyping dengan sel B $(88,89 \%)$ dan sel $\mathrm{T}(11,11 \%)$.Hal ini 
Jurnal Insan Farmasi Indonesia, 3(2) Desember 2020 (361-368)

Nazhipah Isnani

p-ISSN 2621-3184 ; e-ISSN 2621-4032

doi: $10.36387 /$ jifi.v3i2.585

sesuai dengan data penelitian sebelumnya di Indonesia bahwa LLA terbanyak dengan immunophenotyping sel $\mathrm{B}^{8,10}$. Selanjutnya, pada tabel II dilakukan analisis dengan menggunakan regresi linear. Hasil analisis dengan regresi linier diperoleh bahwa faktor usia mempengaruhi terhadap toksisitas hepatologi pada nilai SGOT karena $\mathrm{p}<0,05$. Hepatoksisitas pada penderita LLA berhubungan dengan konsentrasi 6TGN pada sel darah merah. Konsentrasi 6-TGN lebih rendah pada pasien berusia 6 tahun atau kurang dari pada pasien yang lebih tua ${ }^{6,11}$. Kemudian, pada nilai koefisien korelasi minggu kemoterapi diperoleh hasil negatif yaitu $-0,045$, ini berarti bahwa semakin lama minggu kemoterapi maka nilai parameter SGOT pada subyek penelitian tersebut akan semakin turun. Hal tersebut berdasarkan teori terjadi karena ada faktor lain yang mempengaruhi penurunan nilai SGOT yaitu seperti pemberian suplemen hati untuk menormalkan nilai SGOT pasien. Ini

sejalan dengan penelitian terdahulu bahwa tidak ada hubungan yang signifikan antara konsentarsi 6-TGN dalam darah dengan lama penggunaan 6-MP ${ }^{6}$.

Tabel 2. Hasil analisis regresi linier faktor yang mempengaruhi toksisitas hepatologi 6-MP pada nilai SGOT

\begin{tabular}{lcc}
\hline Variabel & $\begin{array}{c}\text { Koefisien } \\
\text { korelasi }\end{array}$ & $\mathbf{p}$ \\
\hline Usia & 0,381 & $0,036^{*}$ \\
Berat Badan & 0,197 & 0,184 \\
Minggu & $-0,045$ & 0,420 \\
kemoterapi & & \\
\hline
\end{tabular}

Keterangan : *signifikan

Tabel 3. Hasil analisis regresi linier faktor yang mempengaruhi toksisitas hepatologi 6-MP pada nilai SGPT

\begin{tabular}{lcc}
\hline Variabel & $\begin{array}{c}\text { Koefisien } \\
\text { korelasi }\end{array}$ & $\mathbf{P}$ \\
\hline Usia & 0,334 & 0,060 \\
Berat Badan & 0,383 & $0,036^{*}$ \\
Minggu & 0,072 & 0,373 \\
kemoterapi & & \\
\hline
\end{tabular}

Keterangan : *signifikan

Pada Tabel III dilakukan analisis antara karakteristik pasien dengan toksisitas hepatologi SGPT. Berdasarkan hasil analisis diatas teradapat nilai yang signifikan yaitu sebesar 0,036 $(\mathrm{P}<0,05)$ pada berat badan. Hal ini berarti, berat badan mempengaruhi toksistas hepatologi 
Jurnal Insan Farmasi Indonesia, 3(2) Desember 2020 (361-368)

Nazhipah Isnani

p-ISSN 2621-3184 ; e-ISSN 2621-4032

doi: $10.36387 /$ jifi.v3i2.585

dari 6-MP. Dalam penelitian terdahulu

dijelaskan bahwa ada hubungan antara

kelebihan berat badan dengan

peningkatan serum SGPT, yaitu

semakin tinggi nilai IMT (semakin

obesitas/berat badan) seseorang maka

semakin tinggi seseorang tersebut

mengalami risiko perlemakan hati sehingga meningkatkan nilai SGPT.

Terjadinya perlemakan hati ini dapat disebabkan oleh Penggunaan obat ${ }^{12}$. Kemudian, pada nilai koefisien korelasi variabel usia, berat badan dan minggu kemoterapi bernilai positif, hal ini menunjukkan bahwa semakin tua usia, semakin besar berat badan seseorang dan semakin lama minggu kemoterapi maka semakin tinggi juga nilai SGPT pada subyek penelitian tersebut.

\section{KESIMPULAN}

Terdapat hubungan antara karakteristik pasien dengan toksisitas hepatologi, yaitu pada usia dengan SGOT dan berat badan dengan SGPT dengan nilai $\mathrm{P} 0,036(\mathrm{P}<0,05)$.

\section{DAFTAR PUSTAKA}

1. Kementrian Kesehatan, 2011, Pedoman Penuaan Dini Kanker Pada Anak, Kesehatan Ridirektorat Jenderal Pp \& Pldirektorat Pengendalian Penyakit Tidak Menular, Jakarta.

2. Suryaningrat, F,R., Primadi, A., Chairulalfatah, A., 2019, Perbandingan Efektifitas Antara Monoterapi Empiris Seftazidime dan Sefepim pada Anak Leukemia Limfoblastik Akut dengan Demam Neutropenia, Sari Pediatri, 21 (2) :81-88.

3. Teheteru, E, S., 2011, Gambaran Tingkat Remisi pada LeukemiaLimfoblastik Akut setelah Fase Induksi diBangsal Kanker Anak RS Kanker "Dharmais", Indonesian Journal of Cancer, 5 (4) :159-162.

4. Brandalise, R.S., Pinheiro, V.S., Aguiar, S.S., et al, 2010, Benefits of the Intermittent Use of 6Mercaptopurine and Methotrexate in Maintenance Treatment for Low-Risk Acute Lymphoblastic Leukemia in Children: Randomized Trial From the Brazilian Childhood Cooperative Group-Protocol ALL-99, $J$ of Clin Onc, 28 (11) : 1911-1918.

5. Vagace, J.M and Gervasini. G., 2011, Acute Leukemia - The Scientist's Perspective and Challenge, editored in Mariastefania Antica, 391-414, InTech Europe.

6. Beaumais, T. A. D., Fakhoury, M., Medard, Y., et al, 2010, 
Jurnal Insan Farmasi Indonesia, 3(2) Desember 2020 (361-368)

Nazhipah Isnani

p-ISSN 2621-3184 ; e-ISSN 2621-4032

doi: $10.36387 /$ jifi.v3i2.585

Determinants of Mercaptopurine Toxicity in Paediatric Acute Lymphoblastic Leukimia Maintenance Therapy, Br J of Clin Pharmacol, 71 (4) : 575-584.

7. Pinontoan, E., Mantik, $\mathrm{M}$ and Rampengan, N., 2012, Pengaruh Kemoterapi terhadap Profil Hematologi pada Penderita Leukimia Limfoblastik Akut, Ilmu Kesehatan Anak FK Unsrat, Manado.

8. Supriyadi, E., Widjajanto, P.H., Purwanto, I., et al, 2011, Immunophenotypic Patterns of Childhood Acute Leukemias in Indonesia, Asian Pac $J$ Can Prevent, 12 : 3381-3387.

9. National Cancer Institute, 2014, Childhood Acute Lymphoblastic Leukemia Treatment, http://www.cancer.gov/cancertopics/ pdq/treatment/Child ALL, diakses tanggal 3 Mei 2014.

10. Rini, T. A., Aisyi, M., Sari, Y., and Edi, S.T., 2009, Karakteristik Leukemia Limfoblastik Akut pada Anak di Rumah Sakit Kanker Dharmais 2000-2008, Ind J Cancer, 4 (4) : 137-140.

11. Maria, E, S., Ulrikka, N., Sussane, R., Ditte, S., Jacob, N., Kim, V., Finn, W., Joh, K., Arja, H-S., Kjeld, S., 2017, Hepatotoxicity During Maintenance Therapy and Prognosis in Children With Acute Lymphoblastic Leukemia, Journal of Pediatric

Hematology/Oncology, 39 (3) : 161-166.

12. Toksvang, L, N., Schmidt, M,S., Arup, S., Larsen, R, H., Frandsen, T, L., Schmiegelow, K., Rank, C, U., 2019, Hepatotoxicity during 6thioguanine treatment in inflammatory bowel disease and childhood acute lymphoblastic leukaemia : Asystematicreview, https://journals.plos.org/plosone/ar $\underline{\text { ticle/file?id=10.1371/journal.pone. }}$ 0212157\&type $=$ printable, accesed on $27^{\text {th }}$ November, 2020. 